\title{
Students, Mobile Devices and Classrooms: A comparison of US and Arab Undergraduate Students in a Middle Eastern University
}

\author{
Bibi Rahima Mohammad Abu Taleb ${ }^{1}$, Chris Coughlin ${ }^{1}$, Michael H. Romanowski ${ }^{1}$, Yassir Semmar ${ }^{1} \&$ Khaled \\ Hosny Hosny ${ }^{1}$ \\ ${ }^{1}$ Qatar University, Doha, Qatar \\ Correspondence: Michael H. Romanowski, Qatar University, Doha, Qatar. E-mail: michaelhr@qu.edu.qa
}

Received: July 8, 2017

Accepted: July 19, 2017

Online Published: August 24, 2017

doi:10.5539/hes.v7n3p181

URL: http://doi.org/10.5539/hes.v7n3p181

\begin{abstract}
The use of mobile devices in the university classroom is not limited to Western cultures. Rather universities in the Middle East, particularly in the Gulf Cooperation Countries (GCC) face similar problems regarding smartphone usage in classrooms. This study utilizes Tindell and Bohlander's (2012) survey to compare results regarding cell phones and text messaging in a small private US university to those in a Middle Eastern University located in a GCC country. The authors surveyed 300 randomly selected undergraduate students representing 26 majors located in seven different colleges to gain an understanding of their smartphones use in university classrooms. Comparison with US students demonstrates these students share a great deal of similarities although several findings indicate differences. To address the similarities and difference, the authors discuss globalization and relevant issues regarding the role culture plays in the use of this technology.
\end{abstract}

Keywords: mobile phones, texting, classroom distractions, academic dishonesty, GCC university students

\section{Introduction}

The use of mobile phones and devices is an integral part of modern society considered by many as a necessary communication device for daily living. According to Post (2011), smartphones are owned by $99.8 \%$ of college students while Dahlstrom and Bichsel (2015) report that $86 \%$ of undergraduates own smartphones. In the Middle East, $72 \%$ of smartphone owners are under the age of 34 and mobile phone usage is rising with experts predicting the region will become the second-largest mobile phone population in the world (Go-Gulf, 2014). In particular, Qatar boasts the highest percentage of smartphone usage with $75 \%$ followed by the UAE at $73 \%$ (Go-Gulf, 2014). Worldwide university classrooms are affected by student use of mobile devices and universities in the Middle East, particularly Gulf Cooperation Countries (GCC) face problems regarding smartphone usage in classrooms. Since there is a significant rise in smartphone usage in the GCC, it is important to consider how university classrooms in a much different culture than that of the US are affected by this increase. With that in mind, this study uses Tindell and Bohlander's (2012) survey of undergraduate students to compare and contrast results regarding smartphones and text messaging in a small private university to those in a GCC university.

\section{Literature Review}

\subsection{Reliance on Mobile Devices}

Cheever et al. (2014) state over "the last two decades mobile phones have made the transition from being simple communication tools to sophisticated Wireless Mobile Devices (WMDs) commonly referred to as "smartphones"” (p. 290). Utilized on a daily basis, the dependency on mobile devices creates "a culture of connectedness in which users access their WMDs everywhere and at any time" (Cheever et al., 2014, p. 290). Roberts, Yayaand Manolis (2014) explained "an increasing reliance on cell-phones among young adults and college students may signal the evolution of cell-phone use from a habit to an addiction" (p. 254). Khalaf (2014) used the term "mobile addict" to describe smartphone users age 13-24. He noted that mobile addicts "launched smartphone or tablet apps more than 60 times per day a growth rate of 123\% between 2013 and 2014" (para. 3). College students "reported spending the most time texting (94.6 minutes per day), sending e-mails (48.5 minutes), checking Facebook (38.6 minutes), surfing the Internet (34.4 minutes), and listening to their iPods (26.9 minutes)" (Roberts et al., 2014, p. 257). Furthermore, Morahan-Martin and Shumacher (2000) found that "almost three-fourths of undergraduate Internet users surveyed (72.8\%) reported at least one symptom indicating Internet use is causing problems while 
$8.1 \%$ indicated four or more symptoms and were classified as pathological Internet users" (p. 21). However, it is often the case that smartphone users do not consider their usage as excessive. Richter (2015) found that "61 percent of the respondents claim to use their own device less frequently than the people around them-a misperception that is not entirely unlike addict behavior" (para. 3).

\subsection{Mobile Devices and University Classrooms}

The dominant use or possible addiction of mobile devices leaves little doubt that undergraduate students' smartphone habits have entered and influenced the university classroom. Research indicates the average college undergraduate checks their phone 11 times a day while attending class (McCoy, 2013). Tindell and Bohlander (2012) found $95 \%$ of students bring their phones to class every day and $92 \%$ use their phones to text message during class time. Furthermore,

Almost all (97\%) admitted to sending or receiving text messages while waiting for class to begin. About $92 \%$ admitted that they have sent or received a text message in class at least once or twice, and $30 \%$ do this every day. Students also notice the texting done by others in the classroom, with $97 \%$ of students indicating they have noticed this at least once or twice (p. 3).

Jesse (2013) reported college student cellphone usage while in class has increased with roughly $80 \%$ of the students admitting to texting at least once in class. Regarding what students are doing on their mobile devices, McCoy (2013) reported that $87 \%$ of students cited texting, $76 \%$ checking email, checking the time was cited by $75 \%$, while social networking was reported by $70 \%$ of respondents followed by Web surfing $(42 \%)$ and game-playing (10\%).

An important question that arises with the extensive use of smartphones in the university classroom is, does smartphone use create a distraction that impacts student learning? McCoy (2013) found that students acknowledge the cost of using digital technologies for non-class reasons when $89 \%$ of respondents stated they "don't pay attention", and 80.5\% "miss instruction", and 38.5\% "distract others". Kuznekoff and Titsworth (2013) found that:

... students who use their mobile phones during class lectures tend to write down less information, recall less information, and perform worse on a multiple-choice test than those students who abstain from using their mobile phones during class" (p. 251). McCoy (2013) states, "respondents said fighting boredom (63\%) in the classroom was a leading reason they used digital devices for non-class activities (p. 28).

Furthermore among first year university students in the US, there was a negative relationship between the use of electronic media including cell phones (calling and texting) and academic performance (self-reported GPA) (Jacobsen \& Forste, 2011). They reported over two-thirds of the university students in their study used electronic media while in class, studying, or doing homework. Junco and Cotton $(2011 ; 2012 \mathrm{c})$ found it is common behavior for college students to send text messages and check Facebook when they study or work on assignments and this negatively related to overall college GPA (2012). Research has demonstrated that Facebook users have lower GPAs and spend fewer hours per week studying compare to non-users (Kirschner \& Karpinski, 2010; Junco, 2012a, 2012b). Furthermore, teachers and students often report that smartphone usage and other challenges such as phones ringing during class are a serious source of irritation and distraction (Campbell, 2005; Burns \& Lohenry, 2010).

The issue of cheating is another concern regarding the use of mobile devices in classes. Studies found students use phones in the classroom to cheat and send messages (Kuznekoff, Munz, \& Titsworth, 2015; Tindell \& Bohlander, 2012; Common Sense Media, 2009). Student reported using smartphones to cheat on exams by accessing information online while taking exams, texting answers to exam questions, taking and distributing photos of exams and saving notes on a phone for reviewing during a test (Katz, 2005; Best College Reviews, n.d.).

\subsection{Students' Perspective toward Mobile Devices Usage and Classrooms}

Regarding students' perspectives toward their use of mobile devices in the classroom, Tindell and Bohlander (2012) reported students did not think there were problems caused by texting in the classroom but "felt there were problems, including a negative impact on classroom learning for the person who is texting, and distraction for those sitting nearby" (p. 4). Berry and Westfall (2015) found that $80 \%$ of nearly 400 college students used their cell phones at least once in a class period with nearly $75 \%$ saying that doing so was either acceptable or sometimes acceptable. The findings suggest that from a student's perspective, the disruptions that occur because of cell phone use in not considered serious. Furthermore, Berry and Westfall (2015) state "80\% of students reported noticing when others check their phones during class, only $12 \%$ thought their own academic 
performance had been adversely affected because of phone use by other students" (p. 67). McCoy (2013) found respondents admitted "such behavior, by themselves and/or students around them, caused them to not pay attention (89\%) and miss instruction (81\%) during class" (p. 28). Tindell and Bohlander (2012) reported "the majority believe they should be allowed to use their phone in class as long as they do not disturb anyone else" (p. 5).

\subsection{Mobile Device Usage in the GCC}

It is quite clear from the above discussion that students extensively use smartphones in U.S university classrooms. However, are these same patterns evident in classrooms in GCC Universities? Alosaimi et al. (2016) found among a sample of 2367 students attending King Saud University, that students (27.2\%) spent more than 8 hours per day using their smartphones. Roughly $75 \%$ of the students used at least four applications per day for social networking and watching news. Forty-three percent of the students reported decreased sleeping hours, and experienced a lack of energy the following day. Students (30\%) reported a more unhealthy lifestyle (ate more fast food, gained weight, and exercised less), while $25 \%$ think their academic accomplishments been harmfully affected.

In the United Arab Emirates, Santos and Bocheco (2014) indicated that 94\% of Emirati students brought mobile phones or smartphones to the classroom. Emirati students reported they were "less distracted by mobile devices in class, with only $28 \%$ feeling they cause more than a little distraction from learning" (p. 87). Furthermore, "Emiratis indicated that mobile devices may be used to send and received text messages during class time as long as they do not distract other students" (p. 87). Belwal, R. and Belwal, S. (2009) found that the majority of university students in Oman feel uncomfortable without the mobile phones and always having them switched on 24/7 indicating their reliance and use in the classroom.

Although there are studies that examine smartphone usage in both a western and Middle Eastern context, few, directly compare and contrast findings utilizing the same survey instrument. Thus, the key objective of this study is to compare and contrast Arab university student's cell phone use and texting with the Tindell and Bohlander's (2012) findings using the same survey instrument translated into Arabic. The purpose is to determine if the different cultural contexts of each university would yield differences in the students' reporting of the views and usage of mobile devices in the classroom.

\section{Method}

Since there is a significant rise in mobile phone population and usage in the Middle East in particular the GCC, it is important to consider the affect of mobile phone usage in university classrooms. Furthermore, it is important to consider smartphone usage in distinctly different cultures. Therefore, this study assesses the extent that students used cell phones and text messaging in one GCC university classrooms and compares these findings with those of Tindell and Bohlander's (2012) findings among US students enrolled in a small private university in northeastern Pennsylvania. These findings are then discussion and placed into a cultural context.

\subsection{Participants}

This study included 300 university students, 150 males and 150 females. The student ages ranged from 17 to 36 , with a mean age of 21 . The students were selected randomly and represent 26 majors located in 7 different colleges. Two students were recruited to administer the questionnaire by spending time at various campus locations facilitating the students' participation as well as visiting a number of classes. Twenty-one percent of the participants were first year students, $26 \%$ second year, $26 \%$ third year, $26 \%$ fourth year with four students not indicating their class standing.

Since the key objective of this study was to compare Arab university student's cell phone use and texting with the Tindell and Bohlander's (2012) findings, Tindell was contacted via email and permission was provided to use the questionnaire from their study (see appendix A). The questionnaire was translated into Arabic and then back translated to English in order to check for accuracy. Both Arabic and English versions were distributed allowing the participants to respond in either Arabic or English. The university's Institutional Review Board approved the study prior to implementation. All participants signed a consent form, were given details about the study, informed they could skip any question or withdraw from the study at any time and provided with contact information if they wished to follow up on any aspects of the study.

\section{Results}

The results are structured in order to compare findings from Tinder and Bohlander's study using (US\%) to provide percentages from Tinder and Bohlander's study in order to make the comparison. Please note that whenever the percentage of responses differs from $100 \%$, on any of the reported data, it is because of missing data, indicating a non-response by at least one participate to that particular item on the questionnaire (Also, 
please note, the Tables provide the findings from this study, please refer to Tindell and Bohlander's (2012) for a more thorough description and presentation of their findings).

\subsection{Student Mobile Phone Usage}

Of the 300 participants, 296 (99\%) (US 99\%), reported having a cell phone, 86\% (US 95\%) stated they bring their cell phones to class and 39\% (US 9\%) responded they turn the phone off during class, $76 \%$ (US 91\%) set their phone to vibrate and $27 \%$ indicated they set their phone to "ring" during class. About $50 \%$ of the students report being distracted at least once during class by another student's cell phone "going off", while $25 \%$ report "that has never happened" and $23 \%$ report it "happens frequently". Roughly $50 \%$ if the participants reported that their phones have accidently "gone off" in class, but that it has only happened once or twice. Examining these frequencies students in this study are less likely to turn their phones off for class and are more likely to set their phone to ring in class. In addition, the undergraduates reported their phone as "gone off". However, this data is not reported in the US study.

Similar to US students, Arab undergraduates use their smartphones in class. Results from this study indicated 92\% (US 97\%) admitted they have sent or received a text message in class with 35\% (US 30\%) sending or recovering a text everyday. Over 91\% (US 97\%) report seeing other students texting during class and roughly $88 \%$ report that they have text during class. In terms of texting during exams, $61.7 \%$ (US 67.3) reported never seeing another student text during an exam while $77.3 \%$ (US 86\%) never texted during an exam. Table 1 lists the response of the participants in terms of texting during class as well as seeing other student's texting during class.

Table 1. Percent of students texting during class

\begin{tabular}{lccccc}
\hline & \multicolumn{5}{c}{ Frequency } \\
\cline { 2 - 6 } Questionnaire Item & Never & Once or twice & On occasion & Almost every test & Daily every test \\
\hline Student has seen another texting & 2 & 13 & 13.7 & 27.3 & 42.7 \\
before class (n=297) & 7 & 14.7 & 23.7 & 23.7 & 30.7 \\
during class ( $\mathrm{n}=299)$ & 61.7 & 22 & 10 & 3 & 1.7 \\
during exam (n=296) & & & & 25.3 & 24.7 \\
Student has texted & 6.7 & 12.7 & 29.7 & 16 & 10 \\
before class ( $\mathrm{n}=297)$ & 12.3 & 34 & 27.3 & 3 & 0.3 \\
during class $(\mathrm{n}=299)$ & 77.3 & 13.3 & 6 & & \\
during exam $(\mathrm{n}=300)$ & & & & & \\
\hline
\end{tabular}

In response to the question asking the participants "If you have SENT a text message during an exam, have you provided information about the exam to another student?" 77\% (US 97.3) reported having "never done that", while $3 \%(\mathrm{US}<1 \%)$ reported doing that "almost every or every test". Regarding the question, "If you have RECEIVED a text message during an exam, have you received information about the exam from another student?" 74\% (US 95\%) report having "never done that" and roughly 6\% (US 0\%) report "yes I regularly do this during exams". These findings are consistent with Tindell and Bohlander's and other Western research (Pew Research Center, 2010), media reports (Redden, 2007; Naidoo, 2008; Ryan, 2013; Jaschik, 2013) and research conducted in the Middle East (Bjorklund \& Wenestam, 1999; Dodeen, 2012; Khan \& Balasubramanian, 2012; Manar \& Shameem, 2014). US students did not report regularly receiving information while taking exams whereas $6 \%$ of our sample admitted engaging in this behavior on a regular basis. McCabe (2005) found students using electronic devices during tests and exams is not high at only five percent but there is still a reason for concern. As authors, we consider this an important finding that will be later addressed.

\subsection{Ease of Texting in Class}

Concerning the difficulty of texting in class and during exams, 49\% (US47\%) of the students found it very or somewhat easy to text during class showing findings are quite consistent with the US study (see Table 2). However, $32 \%$ perceived sending a text during an exam somewhat or very difficult compare to US $43 \%$ (see Table 3). 
Table 2. Perceived difficulty texting without instructor's awareness during class

\begin{tabular}{ccccc}
\hline Very easy & Somewhat easy & Neutral & Somewhat difficult & Very difficult \\
\hline 19 & 30 & 28 & 18 & 5 \\
\hline
\end{tabular}

Note. $\mathrm{n}=300$.

Table 3. Perceived difficulty texting without instructor's awareness during an exam

\begin{tabular}{ccccccc}
\hline Very easy & Somewhat easy & Neutral & Somewhat difficult & Very difficult class & Depends on never tried it & Don't know \\
\hline 6.7 & 10 & 12.3 & 8.3 & 23.7 & 6.7 & 31.2 \\
\hline
\end{tabular}

Note. $\mathrm{n}=298$.

In response to the question "Would it be easier to send or receive a text message during an exam?" $60 \%$ responded they did not know. Roughly $12 \%$, which was the next highest response rate, reported it would be "somewhat easier to receive" a text message during an exam. Students in this study indicate that it could be slightly easier to text during an exam because of the instructor. Specifically, students responded that instructors who are "kind/helpful/friendly/cool easy/not strict" make it easier to text in class. This finding will be discussed further.

\subsection{Perceived Problems of Texting}

A fundamental issue regarding texting is what problems if at all does it cause in classrooms. These undergraduates' views regarding problems of text messaging in class somewhat differ from their counterparts in the US. These students (26.9\%) (US 31.5\%) reported that the student loses focus when texting however, American students linked this to poor grades. Only $4.8 \%$ of the surveyed students indicated a concern that people who text would miss important information from the class. Fewer undergraduates in this study (17.3\%) (US $28.9 \%$ ) thought there were no problems regarding texting in class. Both groups of students included similar responses regarding texting as disrespectful, rude and that texting disturbs the instructor (see Table 4).

Table 4. Most common open-ended responses to the question "Do you think that text messaging causes any problems in the classroom?"

\begin{tabular}{lc}
\hline Response Category & Percentage \\
\hline Student loses focus/disturbed & 26.9 \\
Distracts the other students & 18.3 \\
No problem & 17.3 \\
Disturbing for the instructor & 7.6 \\
Disrespectful/rude students & 6.2 \\
Loss of concentration & 5.7 \\
Miss important information & 4.8 \\
\hline
\end{tabular}

Notes. $\mathrm{n}=208$. Students could have more than one response.

Responding to the question "Do you think students should be allowed to text message during class?" several differences arise between US students and undergraduates in this study. US students (US 61.6\%) think it is acceptable to text in class as long as you are not disturbing other students while students in this study reported (38\%). However, these students (20.6\%) (US 4.1\%) justified their texting as long as it pertains to class discussion (see Table 5). 
Table 5. Most common responses to the question "do you think students should be allowed to text message during class?" (check all that apply)

\begin{tabular}{lc}
\hline Response Category & Percentage \\
\hline Yes, I should be allowed to send a text any time I want & 13 \\
Yes, I see No problems with using a cell phone to text in class As long as & 38 \\
I am Not disturbing any other students & 51.6 \\
Yes, but only in emergency situations (e.g., child care, or illness) & 20.6 \\
Yes, but only if the message pertains to class discussion & 14.3 \\
No, it is never okay to send a text message during class & \\
\hline
\end{tabular}

Note. $\mathrm{n}=300$. Students could have more than one response.

\subsection{Instructors, Classrooms and Texting}

Regarding the statement, "If college instructors only knew about text messaging in the classroom, they would be shocked", findings are similar with Tindell and Bohlander who found the most common response was the amount of texting that occurred (see Table 6). However unlike US students, these undergraduates indicated that professors would be shocked by the content in the text messages. A possible explanation for this concern expressed by these undergraduates is the context of this study and the conservative society and the religion and culture of the university. Speaking to several students informally for context and clarity provided the following example. Students might use obscene language or profanity in a text and if a professor or possible an adult would see this it would appear shocking to the reader. This would not be an issue in the US, hence the omission by US students regarding the "context" of text messages.

Table 6. Most common response to the question: "if college instructors only knew about text messaging in the classroom, they would be shocked."

\begin{tabular}{lc}
\hline Response Category & Percentage \\
\hline Amount/quantity & 10.5 \\
Important need to text & 10.5 \\
The content/text information & 8.6 \\
The negative effects & 5.7 \\
The truth & 2.9 \\
The funny things being shared & 2.9 \\
\hline
\end{tabular}

Note. $\mathrm{n}=105$. Students could have more than one response.

Regarding conditions that make it easier to text in class, in terms of both classroom and teacher characteristics, Tindell and Bohlander found $32.9 \%$ of the students responded that it is easier to text in a class when the "instructor does not have specific policy and doesn't seem to mind texting behavior; more laid back and relaxed" compare to $37.2 \%$ of the students in this study. In terms of the classroom, roughly $60 \%$ (90\% US) of students surveyed responded that large classrooms and large number of students were classroom characteristics that make it easier to text (Tables $7 \& 8$ ).

Table 7. Most common open-ended responses to the question "what characteristics of the classroom layout make it easier to text message during class?"

\begin{tabular}{lc}
\hline Response Category & Percentage \\
\hline Large classrooms & 31.1 \\
Large number of students & 28.8 \\
\hline
\end{tabular}




\begin{tabular}{lc}
\hline Sitting in the back of the classroom & 5 \\
Noisy classroom & 2.7 \\
Students sitting too close & 2.2 \\
\hline
\end{tabular}

Note. $\mathrm{n}=180$. Students could have more than one response.

Table 8. Most common open-ended responses to the question "what instructor characteristics make it easier to text message during class?"

\begin{tabular}{lc}
\hline Response Category & Percentage \\
\hline Kind/helpful teacher/friendly/cool easy/not strict & 37.2 \\
Lazy/careless teacher & 9.6 \\
Boring teacher/boring way of teaching & 8.6 \\
Ignorant/unprepared/bad/rude teacher & 8.1 \\
Long and boring lectures/subjects & 3.5 \\
Losing focus/lack of concentration & 3.5 \\
Easily distracted teachers & 2.5 \\
Instructor leaving class/using cell phone & 2 \\
\hline
\end{tabular}

Note. $\mathrm{n}=196$. Students could have more than one response.

\subsection{Mobile Phone Policies}

Concerning students' views on having a policy for cell phone use, $41.5 \%$ of the students in this study reported there is no need for a formal policy compare to $9.7 \%$ of US students. US students $(23.7 \%)$ indicated cell phone use should be allowed if not disturbing anyone and/or during breaks while only $3.4 \%$ of students in this study agreed. So, from the findings, it appears the majority of these undergraduates do not believe there should be a formal policy on cell phone use and students should monitor their own cell phone usage as not to disturb the class or other students in the class in comparison to US students who think a more formal policy is needed. As can be seen from Table 9, roughly $90 \%$ of these students responded that a cell phone policy should allow students to have cell phones in class.

Table 9. Responses to the question "what do you think should be the policy on cell phone use during class?"

\begin{tabular}{lc}
\hline Response Category & Percentage \\
\hline Cell phones may be kept on the student, but must be placed on vibrate. & 37.7 \\
Cell phones may be used to send and receive text messages during class as long as this is not & 17.7 \\
distracting other students or is not exam material. & 16 \\
Cell phones may be kept on the student, but must be placed on vibrate. & 12.3 \\
Cell phones must be turned off and placed on the desk in front of each student. & 7.7 \\
Cell phones may be kept on the student, and may be left on ring, but not used. & 4 \\
\hline
\end{tabular}
Note. $\mathrm{n}=284$.

When asked to provide suggestions for a cell phone use policy, $41.5 \%$ of undergraduatestudents offered no suggestions while 2.5\% suggested students should be "kicked out of class" if they use their cell phones (see Table 10). As indicated by the data, students feel quite strongly that cell phones in class should be allowed and cell phone use acceptable with few if any restrictions. 
Table 10. Most common responses to the question "what do you think should be the policy on cell phone use during class?"

\begin{tabular}{lc}
\hline Response Category & Percentage \\
\hline None & 41.5 \\
Only in emergency situations & 11.9 \\
Phone on silent/no vibrate & 5 \\
Lockers for keeping cell phones (baskets to collect cell phones) & 3.4 \\
Don't disturb people & 3.4 \\
Kick out students who use phone/distract others & 2.5 \\
\hline
\end{tabular}

Note. $\mathrm{n}=118$. Students could have more than one response.

\section{Discussion}

These findings suggest similarities and few major differences between Arab undergraduates and US students regarding their use of mobile devices in university classrooms. There are several arguments that can be advanced to explain these finding. A strong argument can be made that globalization accompanied with "these technologies have accelerated the dissemination of a heavily Western dominant global culture in the Arab world" (Wiest \& Eltantawy, 2015, p. 125). This is reflected in the similarities in responses between Arab and US undergraduates' responses suggest a growing embracing of Western culture. Although there are similarities regarding mobile phone usage in the classroom or at least similarities located in Middle Eastern "cell phone culture", it is important to remember that US and Middle Eastern cultures still have significantly different cultures that transfer to the classroom.

It is worth noting the university where this study was conducted is ranked as one of the top 10 most international universities worldwide based on the "proportion of international staff, proportion of international students and proportion of research papers published with at least one co-author from another country" (Bothwell, 2016). With that in mind, we need to consider how cultural values and norms could play a role in some of the differences in these findings. For example, findings indicated that six percent of the undergraduates surveyed regularly received information while taking exams. Although a low percentage, there is some consistency in this behavior raising concerns over the different definitions and understanding of academic integrity for students from different countries (Redden, 2007). Lahur (2004) found in many cultures, grades and results receive more value than the learning process creating situations where students are more likely to engage in academic dishonestly instead of learning in order to secure good grades. Furthermore, Magnus, Polterovich, Danilov and Savvatee (2002) found students from different countries have a different attitude toward cheating and also the design of the educational system such as the grading system, severity of punishment and the number of students in classes, can also influence cheating. Therefore, student diversity in the two studies must be considered and how this influences students' view of learning and teachers are topics for future research.

The authors of this study agree with Tindell and Bohlander (2012) who argue "Having a cell phone policy in place is not enough, however. Faculty must enforce the policy for it to be effective" (p. 7). However in this particular context, issues of nationality and culture play a significant role in how this policy is defined and enforced. This must be taken into consideration with any policy that restricts cell phone usage in the class at this and similar universities. In closing, we know that whatever occurs in culture seeps into the classroom where there is no screen door. This is evident with mobile phone use. However, the more extensive issue here is not so much the widespread use of digital devices worldwide in classrooms but rather there is a need to consider the wider culture when multitasking has become the norm. The concern is why students have a habitual need to be on-line even though it reduces their ability to pay attention and their lack of understanding or acknowledging how this interferes with their learning and academic success. How universities will adapt and address this issue is and should be of great concern. 


\section{References}

Alosaimi, F. D., Alyahya, H., Alshahwan, H., Al Mahyijari, N., \& Shaik, S. A. (2016). Smartphone addiction among university students in Riyadh. Saudi Arabia. Saudi Med J., 37(6), 675-683. https://doi.org/10.15537/smj.2016.6.14430

Belwal, R., \& Belwal, S. (2009). Mobile phone usage behavior of university students in Oman. In NISS '09 Proceedings of the 2009 International Conference on New Trends in Information and Service Science, IEEE Computer Society (pp. 954-962). https://doi.org/10.1109/NISS.2009.65

Berry, M. J., \& Westfall, A. (2015). Dial D for distraction: The making and breaking of cell phone policies in the college classroom. College Teaching, 63(2), 62-71. https://doi.org/10.1080/87567555.2015.1005040

Best College Reviews. (n.d.). Cheating in college: The numbers and research. Retrieved from http://www.bestcollegereviews.org/cheating/

Bjorklund, M., \& Wenestam, C. (1999). Academic cheating: Frequency, methods, and causes. In European Conference on Educational Research. Lahti, Finland. Retrieved from http://www.leeds.ac.uk/educol/documents/00001364.htm

Bothwell, E. (2016, January 14). The world's most international universities 2016. Retrieved from $\mathrm{https}$ ://www.timeshighereducation.com/features/200-most-international-universities-world-2016

Burns, S. M., \& Lohenry, K. (2010). Cellular phone use in class: Implications for teaching and learning: A pilot study. College Student Journal, 44(3), 805-810.

Campbell, S. W. (2005). Perceptions of mobile phones in college classrooms: Ringing, cheating, and classroom policies. Communication Education, 55(3), 280-294. https://doi.org/10.1080/03634520600748573

Cheever, N. A., Rosen, L. D., Carrier, L. M., \& Chavez, A. (2014). Out of sight is not out of mind: The impact of restricting wireless mobile device use on anxiety levels among low, moderate and high users. Computers in Human Behavior, 37, 290-297. https://doi.org/10.1016/j.chb.2014.05.002

Common Sense Media. (2009, June 18). National poll reveals students' attitudes toward hi-tech cheating and highlights need for parents and educators to set guidelines and address consequences. Retrieved from https://www.commonsensemedia.org/about-us/news/press-releases/35-of-teens-admit-to-using-cell-phonesto-cheat

Dahlstrom, E., \& Bichsel, B. (2015). ECAR study of undergraduate students and information technology. EDUCAUSE Center for Analysis and Research. Retrieved from http://net.educause.edu/ir/library/pdf/ss15/ers1510ss.pdf

Dodeen, H. M. (2012). Undergraduate student cheating in exams. Damascus University Journal, 28(1), 37-55.

Go-Gulf. (2014, January 8). Smartphone Usage in the Middle East-Statistics And Trends. Retrieved from https://www.infinitemonkeys.mobi/blog/smartphone-usage-in-the-middle-east-statistics-and-trends-infograp hic/

Jacobsen, W. C., \& Forste, R. (2011). The wired generation: Academic and social outcomes of electronic media use among university students. Cyberpsychology, Behavior, and Social Networking, 14(5), 275-280. https://doi.org/10.1089/cyber.2010.0135

Jaschik, S. (2013). Texting in class. Inside Higher Education. Retrieved from https://www.insidehighered.com/news/2013/10/21/study-documents-how-much-students-text-during-class

Jesse, G. (2013). Like, tweet, or pin: College students and their current use of social media. Issues in Information Systems, 14(1), 403-414.

Junco, R. (2012a). The relationship between frequency of Facebook use, participation in Facebook activities, and $\begin{array}{lllll}\text { student engagement. } \quad \text { Computers } \& \quad \text { Education, } & \text { 58(1), }\end{array}$ https://doi.org/10.1016/j.compedu.2011.08.004

Junco, R. (2012b). Too much face and not enough books: The relationship between multiple indices of Facebook use and academic performance. Computers in Human Behavior, 28(1), 187-198. https://doi.org/10.1016/j.chb.2011.08.026

Junco, R., \& Cotton, S. R. (2011). Perceived academic effects of instant messaging use. Computers \& Education, 56, 370-378. https://doi.org/10.1016/j.compedu.2010.08.020 
Junco, R., \& Cotton, S. R. (2012c). No A 4 U: The relationship between multitasking and academic performance. Computers \& Education, 59(2), 505-514. https://doi.org/10.1016/j.compedu.2011.12.023

Katz, J. E. (2005). Mobile phones in educational settings. In K. Nyiri (Ed.), A sense of place: The global and the local in mobile communication (pp. 305-317). Vienna: Passagen.

Khalaf, S. (2014). The rise of the mobile addict. Retrieved from http://flurrymobile.tumblr.com/post/115191945655/the-rise-of-the-mobile-addict

Khan, Z. R., \& Balasubramanian, S. (2012). Students go click, flick and cheat. E-cheating, technologies and more. Journal of Academic and Business Ethics, 6, 1-26.

Kirschner, P. A., \& Karpinski, A. C. (2010). Facebook and academic performance. Computers in Human Behavior, 26(6), 1237-1245. https://doi.org/10.1016/j.chb.2010.03.024

Kuznekoff, J. H., Munz, S., \& Titsworth, S. (2015). Mobile phones in the classroom: Examining the effects of texting, twitter, and message content on student learning. Communication Education, 64(3), 344-365. https://doi.org/10.1080/03634523.2015.1038727

Kuznekoff, J. H., \& Titsworth, S. (2013). The impact of mobile phone usage on student learning. Communication Education, 62(3), 233-252. https://doi.org/10.1080/03634523.2013.767917

Lahur, A. M. (2004). Plagiarism among Asian students at an Australian university offshore campus: Is it a cultural issue? In A pilot study. Retrieved from http://www.herdsa.org.au/wp-content/uploads/conference/2004/PDF/A033-jt.pdf

Magnus, J. R., Polterovich, V. M., Danilov, D. L., \& Savvateev, A. V. (2002). Tolerance of cheating: An analysis across countries. The Journal of Economic Education, 33(2), 125-136. https://doi.org/10.1080/00220480209596462

Manar, H., \& Shameem, F. (2014). Attitude of students towards cheating and plagiarism: University case study. Journal of Applied Sciences, 14, 748-757. https://doi.org/10.3923/jas.2014.748.757

McCabe, D. L. (2005). Cheating among college and university students: A North American perspective. International Journal for Educational Integrity, 1(1), 1-11.

McCoy, B. R. (2013). Digital distractions in the classroom: Student classroom use of digital devices for non-class related purposes. Journal of Media Education, 4(4), 5-14.

Morahan-Martin, J., \& Shumacher, P. (2000). Incidence and Correlates of Pathological Internet use among College Students. Computers in Human Behavior, 16(1), 13-29. https://doi.org/10.1016/S0747-5632(99)00049-7

Naidoo, A. (2008). UAE students justify cheating, research reveals. In Gulf News. Retrieved from http://gulfnews.com/news/uae/education/uae-students-justify-cheating-research-reveals-1.126060

Pew Research Center. (2010). Teens and mobile phones. Retrieved from http://www.pewinternet.org/2010/04/20/teens-and-mobile-phones-3/

Post, H. (2011, May 25). 99.8\% of college students have cellphones: Ball state study. Retrieved from http://www .huffingtonpost.com/2010/06/28/998- of - college - students-h_n_628161.html

Redden, E. (2007, May 24). Cheating across cultures. In Inside Higher Education. Retrieved from https://www.insidehighered.com/news/2007/05/24/cheating

Richter, F. (2015, July 23). Infographic: America's growing smartphone addiction. Retrieved from http://www.statista.com/chart/3666/frequency-of-smartphone-usage/

Roberts, J. A., Yaya, L. H. P., \& Manolis, C. (2014). The invisible addiction: Cell-phone activities and addiction among male and female college students. Journal of Behavioral Addictions, 3(4), 254-265. https://doi.org/10.1556/JBA.3.2014.015

Ryan, J. (2013). They text in class. The Atlantic. Retrieved from https://www.theatlantic.com/education/archive/2013/10/study-80-of-college-students-say-they-text-in-class/ $280859 /$

Santos, I. M., \& Bocheco, O. (2014). Students' perceptions of mobile devices usage during class time and policy suggestions for appropriate practices. In M. Kalz, Y. Bayyurt, \& M. Specht (Eds.), Mobile as Mainstream-Towards Future Challenges in Mobile Learning (pp. 81-90). 13th World Conference on Mobile and Contextual Learning, Istanbul, Turkey, Proceedings, Switzerland: Springer International Publishing. 
Smith, A. (2012). Nearly half of American adults are smartphone owners. Pew Internet \& American Life Project. Retrieved from http://www.pewinternet.org/Reports/2012/Smartphone-Update-2012.aspx

The 2015 Digital Marketer. (2015). Experian marketing services. Retrieved from http://www.experi-an.com/assets/marketing-services/p/2015-digital-marketer-report.pdf?SP_MID=2916\&S P_RID=-315631\&elq=dbab6eb12a2a4809bf22ec76a8632a55\&elqCampaignId=2270\&elqaid=2916\&elqat= 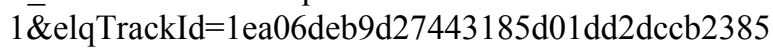

Tindell, D. R., \& Bohlander, R. W. (2012). The use and abuse of cell phones and text messaging in the classroom: A survey of college students. College Teaching, 60(1), 1-9. https://doi.org/10.1080/87567555.2011.604802

Wiest, J. B., \& Eltantawy, N. (2015). Mediatization in the Arab world: A cross-cultural comparison of new media use. Online Journal of Communication and Media Technologies, 5(2), 120-142.

\section{Appendix A}

\section{Survey Questions Related to Cell Phone Use}

Gender: Male

$$
\text { Female }
$$

Academic Major:

Age

Year at Qatar University

$1^{\text {st }}$ Year
$2^{\text {nd }}$ Year
3rd Year
$4^{\text {th }}$ Year

\section{Section 1: General Experience With Text Messaging}

1. Do you have a cell phone that can be used for text messaging?

A. Yes

B. No

2. What types of messages have you sent with your phone? (Check all that apply)

I don't send any type of text message

Standard text

Email

Facebook/MySpace

Twitter

Pictures

3. Do you bring your cell phone to class?

Yes, always

Yes, sometimes

No, never

4. When you are in class, what is the typical status of your cell phone?

My cell phone is turned off

My cell phone is on vibrate

My cell phone is set to ring

Section 2: Observation of the Use of Cell Phones by OTHERS 
5. Have you ever seen another student send or receive a text message while waiting for class to begin?

(Check only one response)

No, I have never noticed this

Yes, I have noticed this once or twice before

Yes, I have noticed this occasionally

Yes, I notice this almost everyday

Yes, this happens everyday

6. Have you ever seen another student send or receive a text message while class is in session? (Check only one response)

No, I have never noticed this

Yes, I have noticed this once or twice before

Yes, I have noticed this occasionally

Yes, I notice this almost everyday

Yes, this happens everyday.

7. Have you ever seen another student send or receive a text message during an exam? (Check only one response)

No, I have never noticed this

Yes, I have noticed this once or twice before

Yes, I have noticed this occasionally

Yes, I notice this almost every day

Yes, this happens every day.

8. Have you ever been distracted by another student's cell phone "going off" during class? (Check only one response)

No, this has never happened

Yes, this has happened at least once.

Yes, this happens frequently.

Section 3: Students' Own Use of a Cell Phone in the Classroom.

9. Has your cell phone ever "gone off" accidentally during a class because you forgot to put it on vibrate or turn it off? (Check only one response)

No, this has never happened because I never bring my cell phone to class.

No, this has never happened, even though I bring my cell phone to class.

Yes, this has happened once or twice.

Yes, this has happened at least a few times.

10. Have you, yourself, ever sent or received a text message while waiting for class to begin? (Check only one response)

No, I have never done this

Yes, I have done this once or twice before

Yes, I have done this occasionally

Yes, I do this almost every day

Yes, I do this every day

11. Have you, yourself, ever sent or received a text message while class was in session? (Check only one response)

No, I have never done this

Yes, I have done this once or twice before 
Yes, I have done this occasionally

Yes, I do this almost every day

Yes, I do this every day

12. Have you, yourself, ever sent or received a text message during an exam? (Check only one response) No, I have never done this

Yes, I have done this once or twice before

Yes, I have done this occasionally

Yes, I do this almost every test

Yes, I do this every test

13. If you have SENT a text message during an exam, have you provided information about the exam to another student? (Check only one response)

Yes, but only once

Yes, I have done this a few times

Yes, I regularly do this during exams

No, I have never done this

14. If you have RECEIVED a text message during an exam, have you received information about the exam from another student? (Check only one response)

Yes, but only once

Yes, I have done this a few times

Yes, I regularly do this during exams

No, I have never done this

Section 4: Students' opinion about issues related to cell phone use in the classroom.

15. How easy is it to send or receive a text message in class without the instructor being aware? (Check only one response)

Very easy

Somewhat easy

Neither easy nor difficult $\bullet$

Some what difficult •

Very difficult

16. Is it easier to send or receive a text message in class? (Check only one response)

Easy in some classes; more difficult in others

I don't know, because I don't try to send text messages, nor do I notice it in others

It is much easier to send

It is somewhat easier to send

It is equally easy to send and receive

It is somewhat easier to receive

It is much easier to receive

I don't know

17. How easy would it be to send or receive a text message during an exam without the instructor being aware? (Check only one response)

Very easy

Somewhat easy

Neither easy nor difficult 
Somewhat difficult

Very difficult

Easy in some classes; more difficult in others

I don't know, because I don't try to send text messages, Nor do I notice it in others.

18 Would it be easier to send or receive a text message during an exam? (Check only one response)

It would be much easier to send -

It would be somewhat easier to send •

It would be equally easy to send and receive $\bullet$

It would be somewhat easier to receive

It would be much easier to receive

I don't Know

19. In which of the following situations do you think a student could text message without the instructor being aware? (Check all that apply)

In no situations - In a very large classroom $(>100)$ only

In a large classroom ( $>40)$ only

In a relatively small classroom $(<25)$

In a small classroom $(<12)$

20. Do you think that text messaging causes any problems in the classroom? If so, please state what those problems are in the space below.

21. Do you think cell phones should be allowed in the classroom? (Check all that apply)

Yes, always

Yes, if using functions such as the calculator or calendar

Yes, but not during exams

Yes, if on vibrate

Yes, but only turned off

No, cell phones should not be allowed at all

22. Do you think that students should be allowed to text message during class? (Check all that apply)

Yes, I should be allowed to send a text any time I want.

Yes, I see No problems with using a cell phone to text in class as long as I am Not disturbing any other students.

Yes, but only in emergency situations (e.g., child care, or illness).

Yes, but only if the message pertains to class discussion.

No, it is never okay to send a text message during class.

23. What do you think should be the policy on cell phone use during class? (Check only one response)

Cell phones must be turned off and placed on the desk in front of each student.

Cell phones may be kept on the student, but must be turned off.

Cell phones may be kept on the student, but must be placed on vibrate.

Cell phones may be kept on the student, and may be left on ring, but Not used.

Cell phones may be used to send and receive text messages during class as long as this is Not distracting other students or is Not exam material.

Cell phones are Not permitted in the classroom under any circumstances.

24. Do you have any other ideas for a good policy on cell phone use? Please describe.

25. What instructor characteristics make it easier to text message during his or her class? List as many as you think are important. 
26. What characteristics of the classroom layout make it easier to text message during class? List as many as you think are important.

Please complete the following statement,

"If college instructors only knew about text messaging in the classroom, they would be shocked."

\section{Copyrights}

Copyright for this article is retained by the author(s), with first publication rights granted to the journal.

This is an open-access article distributed under the terms and conditions of the Creative Commons Attribution license (http://creativecommons.org/licenses/by/4.0/). 